\title{
Editorial
}

\section{Ropivacaine - a worthy replacement for bupivacaine?}

\author{
Brendan T. Finucane MD FRCPC
}

\begin{abstract}
"One more step had now to be taken. We trickled the solution under each others lifted eyelids. Then placed a mirror before us, took pins, and with the head tried to touch the cornea. Almost simultaneously we were able to state jubilantly: 'I can't feel anything'."
\end{abstract}

These words were written by Köller shortly after he had confirmed that cocaine had local anaesthetic properties. ${ }^{1}$ It is a little more than one hundred years since Köller made this monumental discovery. Since that time, hundreds of different local anaesthetic agents have been tested, but few have graduated to the clinical scene.

What do clinicians expect from local anaesthetics today? That depends on the arena in which one finds oneself. Clinicians are primarily interested in local anaesthetics with a low potential for toxicity. In a surgical setting, one would prefer a local anaesthetic which had a rapid onset of action, good penetration, and a reasonable duration of action. If profound relaxation was required, a local anaesthetic which had a predilection for blocking motor fibres would be preferred. In the obstetrical suite, a local anaesthetic which selectively blocked $A \delta$ and $C$ fibres, and one that does not readily cross the placental barrier would be indicated. There is a wide variety of local anaesthetics from which to choose. In most instances, the selection can be tailored to the needs of the individual patient.

In this issue of the Journal, Hickey et al. introduce us to another new local anaesthetic agent - ropivacaine. Do we need another long-acting local anaesthetic agent? Reflection on the historical aspects of local anaesthesia may help put this subject into perspective. Toxicity issues have blemished the history of local anaesthesia since its inception. More than ten fatalities were reported in association with cocaine during the first six years of its use as a local anaesthetic. Scrutiny of its chemical structure by Willstatter ${ }^{2}$ in 1895 resulted in the testing of more than 100 different esters of benzoic acid, none of which proved

Department of Anaesthesia, University of Alberta, Edmonton acceptable until procaine was synthesized by Einhorn ${ }^{3}$ in 1904. Despite its limitations, it was the local anaesthetic of choice for four decades, and to this day references to novocaine (the generic title for procaine) are synonymous with local anaesthesia.

Löfgren ${ }^{4}$ first tested the local anaesthetic properties of the aniline derivatives in 1943 and synthesized lidocaine in 1948. Lidocaine rapidly became the local anaesthetic of choice in the dentist's office, the emergency room, and the operating room. With a resurgence of interest in regional anaesthesia in the nineteen sixties, the need for a longer-acting local anaesthetic agent became apparent. Bupivacaine, another amino-amide compound, was synthesized and was introduced into clinical practice in 1963, and it proved to be a very effective long-acting local anaesthetic agent. In 1979, Albright ${ }^{5}$ in a controversial editorial, drew attention to the dangers of the longeracting local anaesthetic agents, bupivacaine and etidocaine, if they were to be accidentally injected intravascularly. A subsequent report ${ }^{6}$ by the manufacturers presented details of 12 cardiac arrests following intravascular injections of bupivacaine, ten of which proved fatal. Subsequent studies have shown that bupivacaine may induce malignant arrhythmias at plasma concentrations not much greater than those that cause seizures. The a aetiology of this phenomenon is still speculative. However, studies in animals ${ }^{7}$ indicate that bupivacaine, when injected intravascularly, induces a dose and ratedependent depression of $\mathrm{V}$-max, resulting in re-entrant arrhythmias and cardiac depression, sometimes culminating in cardiac arrest. Therefore, the impetus for the development of ropivacaine stems from the shortcomings of an otherwise excellent local anaesthetic agent bupivacaine.

Akerman et al. ${ }^{8}$ have shown that isomers of local anaesthetics are not as toxic as racemic compounds. Ropivacaine, although structurely similar to bupivacaine and mepivacaine, is an isomer, the active ingredient of which is the (S) enantiomer of 1-propyl-2',6'pipecoloxylidine. Its physical/chemical profile is similar to that of bupivacaine. Toxicity studies ${ }^{9-11}$ have been 
carried out in several animal species comparing ropivacaine with bupivacaine and lidocaine, and these indicate that ropivacaine is less cardio-toxic than bupivacaine, and more so than lidocaine. There is also a greater separation between convulsive and lethal doses compared with bupivacaine.

There are limitations on the extent to which one can test acute toxicity of local anaesthetics in humans. The most reliable information to date was reported by Scott et al. ${ }^{12}$ Ropivacaine and bupivacaine were infused intravenously in a ramdomized, double-blind study in 12 volunteers. Bupivacaine induced symptoms of mild CNS toxicity at much lower plasma concentrations than did ropivacaine. They also performed sophisticated non-invasive cardiac monitoring in some of these volunteers, and showed that while both agents induced subtle changes in cardiac contractility and conductivity at sub-convulsive plasma levels, ropivacaine proved to be far less likely to do so than bupivacaine.

The blocking characteristics of ropivacaine have also been tested in animals and humans, and compared with bupivacaine. In equi-potent concentrations the degree of motor blockade is less pronounced with ropivacaine, and there is a greater propensity for blocking $\mathrm{A} \delta$ and $\mathrm{C}$ fibres. ${ }^{13}$ If true, this may prove to be advantageous in obstetric patients in labour and in others suffering from acute and chronic pain.

Ropivacaine has enormous potential as a local anaesthetic agent. It appears to have most of the blocking characteristics of bupivacaine without the cardiotoxic effects. Furthermore, the potential for CNS toxicity appears to be less. However, one should remember that bupivacaine had been used clinically for almost 20 years before Albright focused on the problem of cardiotoxicity. We should also recall the fate of etidocaine, introduced some 15 years ago. Theoretically, this compound had all the necessary attributes to make it the ideal local anaesthetic in the surgical setting. However, clinical evaluation proved anything but satisfactory. Clinical testing of local anaesthetics is far more sophisticated today than it was even 15 years ago. Based on animal and clinical testing in humans today, it is very likely that ropivacaine will replace bupivacaine in the ensuing years.

In summary, mankind has benefited greatly from Köller's discovery of local anaesthesia a little over 100 years ago. Local anaesthesia toxicity, sometimes leading to death, marred the early days of this new era of anaesthesia, but new safer drugs were synthesized. One hundred years later history is repeating itself. Chemists have again produced more synthesized compounds. Molecular manipulations of local anaesthetics allow us to retain the attributes of the original compound while discarding the undesirable features.

\section{La ropivacaïne sonne-t-elle le glas de la bupivacaïne?}

"Il fallait tous deux aller encore plus loin. Après s'être instillé de la solution dans les yeux, nous nous saisimes chacun d' un miroir pour se toucher la cornée avec la tête d'une épingle. Presque en même temps que moi, mon compagnon s'écria: "Je ne sens plus rien".

Lorsqu'il écrit ces phrases, Köller venait de découvrir les propriétés anesthésiques de la cocaïne.' Pendant le siècle qui a suivi, on a bien essayé des centaines d'anesthésiques locaux mais rares sont ceux qui ont fait leurs marques en clinique.

Qu'est-on en droit d'exiger d'un anesthésique local de nos jours? D'abord, qu'il soit peu toxique; ensuite, cela dépend de ce qu'on veut en faire. Pour les interventions chirurgicales, l'anesthésique doit pénétrer facilement les tissus, agir rapidement et pendant assez longtemps. S'il faut de la relaxation musculaire, on voudra privilégier un bloc des fibres motrices alors qu'en obstétrique, c'est un bloc sélectif des fibres « $\mathrm{C}$ » et « $\mathrm{A} \delta$ » sans effet sur le foetus que l'on recherchera. Le vaste choix d'anesthésiques locaux permets habituellement de s'adapter à chaque situation.

Dans ce numéro, Hickey et ses collègues nous dressent le profil d'un nouvel anesthésique local, la ropivacaïne. Il faut un peu retourner dans le temps pour entrevoir le rôle que pourra jouer un autre anesthésique à longue action. La toxicité des anesthésiques locaux a souvent fait la manchette avec plus de dix décès associés à la cocaïne pendant ses six premières années d'usage en anesthésie. Willstat$\operatorname{ter}^{2}$ décrit la structure chimique de la cocaïne en 1895 et dès lors, on essaya sans succès plus d'une centaine de dérivés esters de l'acide benzoïque jusqu'à ce qu'Einhorn $^{3}$ ne synthétise la procaïne en 1904. Malgré ses défauts, cette dernière domina le marché pendant 40 ans et encore aujourd'hui, novocaïne (nom générique de la procaïne) est synonyme d'anesthésie locale.

Löfgren $^{4}$ qui s'intéressait aux propriétés anesthésiques des dérivés de l'aniline dès 1943, synthétisa la lidocaïne en 1948. Celle-ci devint rapidement l'anesthésique favori en cabinet dentaire, à l'urgence et en salle d'opération. Toutefois, pour soutenir la popularité croissante de l'anesthésie régionale dans les années soixante, on dut inventer une anesthésique local à longue action. En 1963, la bupivacaïne, une autre amino-amide fit une entrée 
remarquée en clinique. Seize ans plus tard dans un éditorial controversé, Albright ${ }^{5}$ vint attirer l'attention sur les dangers associés à l'injection intravasculaire accidentelle de deux anesthésiques à longue action, la bupivacaïne et l'étidocaïne. Peu après, le manufacturier présenta les détails de 12 cas d'arrêt cardiaque (dont dix irréversibles) survenus lors d'injections intravasculaires de bupivacaïne. On s'aperçut ensuite que cet anesthésique pouvait entrainer des arythmies graves à une concentration plasmatique légèrement supérieure à celle produisant des convulsions. Même si on ne sait trop pourquoi, chez l'animal, la bupivacaine intraveineuse cause une diminution du V-max proportionnelle à la dose et à la vitesse d'injection; s'ensuivent alors une dépression cardiaque et des arythmies par ré-entrée qui dégénèrent parfois en arrêt cardiaque. ${ }^{6}$ Il fallait donc trouver un anesthésique local qui conserve les multiples qualités de la bupivacaïne sans sa toxicité.

D'après Akerman, les isomères purs d'anesthésiques locaux ne sont pas aussi toxiques que leurs mélanges racémiques. ${ }^{8}$ La ropivacaïne est justement un autre isomère de la structure commune à la bupivacaïne et à la mépivacaïne. Sa partie active est la forme " $S$ » de la 1-propyl-2',6'-pipecoloxylidine et son profil physicochimique est semblable à celui de la bupivacaïne. Chez l'animal, la toxicité de la ropivacaïne se situe entre celle de la bupivacaïne et celle de la lidocaïne. ${ }^{9-11}$ De plus la différence entre les doses convulsive et mortelle de la ropivacaïne est plus grande que celle de la bupivacaïne.

Il est évidemment délicat de mesurer les seuils toxiques chez l'humain. Néanmoins, 12 volontaires ont participé à l'étude randomisée à l'aveugle de Scott et coll. où ces derniers leur perfusaient un anesthésique local par voie intraveineuse; l'apparition de symptômes neurologiques survenait plus précocement avec la bupivacaïne qu'avec la ropivacaïne. ${ }^{12}$ De plus, grâce à certains qui parmi eux se prêtèrent à un monitorage cardiaque non-invasif, l'on sait qu'à des doses infraconvulsives, surviennent des modifications de la contractilité et de la conduction intra-cardiaque plus importantes avec la bupivacaïne qu'avec la ropivacaïne.

Enfin, d'autres études faites chez l'humain et chez l'animal démontrent que la ropivacaïne semble avoir plus d'affinité pour les fibres « $\mathrm{C}$ » et « $\mathrm{A} \delta$ » et moins pour les fibres motrices que la bupivacaïne. ${ }^{13} \mathrm{Ce}$ serait là un net avantage pour l'analgésie obstétricale et pour les autres types de douleurs aiguës ou chroniques.

La ropivacaïne fait naître beaucoup d'espoirs. Elle semble jouir des qualités anesthésiques de la bupivacaïne tout en étant moins toxique pour le cœur et le système nerveux central. Retenons toutefois nos élans en nous rappelant qu'il a fallu près de 20 ans d'usage de la bupivacaïne en clinique avant qu'Albright ne sonne l'alarme au sujet de sa cardiotoxicité. Souvenons nous aussi de l'étidocaïne qui semblait présenter toutes les qualités de l'anesthésique idéal en chirurgie, il y a de ça tout juste 15 ans ; son usage en clinique s'est avéré décevant. Toutefois, l'évaluation clinique des anesthésiques locaux est beaucoup plus pointue de nos jours et jusqu'à maintenant, elle semble indiquer que la ropivacaïne est appelée à remplacer la bupivacaïne.

Il y a 100 ans, la découverte de Köller marquait un grand jour pour l'humanité ; les décès des premières années furent le prélude au développement d'anesthésiques locaux plus sûrs. Aujourd'hui, l'histoire se répète alors que les chimistes sont parvenus à manipuler la structure d'un anesthésique local pour en diminuer la toxicité tout en lui conservant ses qualités.

\section{References}

1 Vandam LD. Some aspects of the history of local ancsthesia. In: Strichartz GR (Ed.). Local Anesthetics, New York: Springer-Verlag 1987; 3.

2 Willstatter $R$. Ueber die synthese des psiknin. Munch Med Wschr 1924; 71: 849-950.

3 Einhorn A, Uhlfelder $E$. Ueber den P-Aminobenzoesaure - diathylamino and piperidoathylester. Justus Liebigs Annalen der Chemic 1909; 371: 131-142.

4 Lofgren $N$. Studies in local anesthetics. Xylocaine, a new synthetic drug. Thesis I. Haeggstrom 1948. Stockholm p 150. Reprinted Worcester Mass. 1958.

5 Albright GA. Cardiac arrest following regional anesthesia with etidocaine or bupivacaine. Anesthesiology 1979; 51: 285-7.

6 Adverse reactions with bupivacainc. FDA Drug Bulletin 1983; 13: 23.

7 Clarkson CW, Hondeghem LM. Mechanism for bupivacaine depression of cardiac conduction: fast block of sodium channels during the action potential with slow recovery from block during diastole. Anesthesiology 1985; 62: 396-405.

8 Akerman B. Hellenberg I, Trossvik C. Primary evaluation of the local anaesthetic properties of the amino amide agent ropivacaine (LEA 103). Acta Anaesthesiol Scand 1988; 32: 571-8.

9 Nancarrow $C$, Rutten A, Runciman $W$ et al. Myocardial and cerebral drug concentrations and the mechanisms of death after fatal intravenous doses of lidocaine, bupivacaine, and ropivacaine in the sheep. Ancsth Analg 1989; 69: 276-83.

10 Reiz S, Nath SW. Cardiotoxicity of LEA 103 - a new amide local anesthetic agent. Acta Anaesthesiol Scand 1989; 33: 93-8. 
11 Moller R, Covino BG. Cardiac electrophysiologic properties of bupivacaine and lidocaine compared with those of ropivacaine, a new amide local anesthetic. Anesthesiology 1990; 72: 322-9.

12 Scott DB, Lee A, Fagan D, Bowler GMR, Bllomfield P, Lundh $R$. Acute toxicity of ropivacaine compared with that of bupivacainc. Anesth Analg 1989; 69: 563-9.

13 Feldman HS, Covino BG. Comparative motor-blocking effects of bupivacaine and ropivacaine, a new amino amide local anesthetic in the rat and dog. Anesth Analg 1988; 67: 1047-52. 